\title{
Communication/Comunicação
}

\section{A semi-nested PCR assay for molecular detection of Paracoccidioides brasiliensis in tissue samples}

\author{
Semi-nested PCR para a detecção molecular de Paracoccidioides brasiliensis em amostras de \\ tecido
}

\section{Andrea Cristine Koishi ${ }^{1}$, Débora Fonseca Vituri ${ }^{1}$, Pedro Sebastião Raimundo Dionízio Filho ${ }^{2}$, Alexandre Augusto Sasaki ${ }^{1}$, Maria Sueli Soares Felipe ${ }^{3}$ and Emerson José Venancio ${ }^{2}$}

\begin{abstract}
Introduction: Paracoccidioidomycosis is a systemic infection caused by Paracoccidioides brasiliensis. Methods: In this study, a semi-nested PCR for paracoccidioidomycosis diagnosis was developed. The primers ITS 1 and ITS4 were used in the first reaction, while the primers MJ03 and ITS1 primer were used in the second reaction. The semi-nested PCR was used to investigate biopsies of five patients with oral lesions that resembled paracoccidioidomycosis. Results: The semi-nested PCR was positive for four samples and negative for a sample from a patient later diagnosed with leishmaniasis. Conclusions: The new semi-nested PCR describe is useful for paracoccidioidomycosis diagnosis.
\end{abstract}

Key-words: Paracoccidioides brasiliensis. Semi-nested PCR. Molecular detection.

\section{RESUMO}

Introdução: A paracoccidioidomicose é uma infecção sistêmica causada pelo Paracoccidioides brasiliensis. Métodos: Neste estudo, uma semi-nested PCR foi desenvolvida para o diagnóstico da paracoccidioidomicose. Os oligonucleotídeos iniciadores ITS1 e ITS4 foram usados na primeira reação, enquanto os oligonucleotídeos iniciadores MJ03 e ITS1 foram usados na segunda reação. A semi-nested PCR foi usada para investigar biopsias de cinco pacientes com lesões orais que se assemelhavam a paracoccidioidomicose. Resultados: A semi-nested PCR foi positiva para quatro amostras e negativa para a amostra de um paciente, posteriormente diagnosticado com leishmaniose. Conclusões: A semi-nested PCR descrita aqui é útil para o diagnóstico da paracoccidioidomicose.

Palavras-chaves: Paracoccidioides brasiliensis. Semi-nested PCR. Detecção molecular.

The thermal dimorphic fungus Paracoccidioides brasiliensis is the etiologic agent of paracoccidioidomycosis (PCM), a systemic mycosis endemic in Latin America ${ }^{1}$.

PCM diagnosis can be determined by direct observation or the culture of clinical samples, histological analyses and serological methods. However, these techniques each have concerns: using direct observation, $P$. brasiliensis yeast cells may not be observed or could be mistaken for other dimorphic fungi ${ }^{1}$; sample culture

1. Program in Experimental Pathology, Department of Pathological Sciences, Londrina State University, Londrina, PR, Brazil. 2. Department of Pathological Sciences, Londrina State University, Londrina, PR, Brazil. 3. Department of Cell Biology, Brasilia University, Brasília, DF, Brazil.

Address to: Dr. Emerson José Venancio. Dept ${ }^{\circ}$ Ciências Patológicas/UEL. Rodovia Celso Garcia Cid (PR-445), KM 380 Campus Universitário, 86051-990 Londrina, PR, Brazil.

Phone: 5543 3371-5732

e-mail: emersonj@uel.br

Received in 03/05/2010

Accepted in 13/07/2010 is slow and frequently negative; in histological analysis, the pseudoepitheliomatous hyperplasia typical of PCM resembles squamous cell carcinoma so closely that it is possible to mistake one for the other; finally, serological assays are highly sensitivity, but not totally specific.

Alternative diagnostic methods for PCM have been developed, including polymerase chain reactions (PCR). The most frequently used target sequences for molecular detection of $P$. brasiliensis by PCR are the $g p 43^{2-4}$ and ribosomal DNA genes ${ }^{5-8}$. PCR assays have been used experimentally to detect $P$. brasiliensis in the serum and tissues of infected mice ${ }^{2,4}$, in artificially contaminated soil and in environmental samples ${ }^{8}$. In PCM patients, PCR has been used on sputa, cerebrospinal fluid and paraffin-embedded tissues ${ }^{3,9,10}$. However, molecular diagnosis of PCM is not used in clinical routine.

Here, we report a semi-nested PCR (snPCR) assay for the molecular detection of $P$. brasiliensis using two universal primers for fungi and a specific primer designed to detect a specific DNA ribosomal sequence of $P$. brasiliensis.

Two strains of P. brasiliensis (LDR1 and $\mathrm{Pb} 18$ ) and one isolate of each of the following fungi, Candida albicans (CR15), Histoplasma capsulatum, Sporothrix schenckii, Cryptococcus sp and Tricophyton rubrum were used. All fungi isolates were maintained on Sabouraud dextrose agar at room temperature, with the exception of $P$. brasiliensis and Cryptococcus sp, which were maintained at $35^{\circ} \mathrm{C}$.

DNA from fungal cells and tissues from mice or patients were extracted by maceration in liquid nitrogen followed by phenolchloroform-isoamyl alcohol treatment and sodium acetate-ethanol precipitation. DNA concentration and purity were determined by spectrophotometry.

Swiss male mice $(n=5)$ were injected with $1.5 \times 10^{6}$ yeast cells of $P$. brasiliensis $\mathrm{Pb} 18$ via the tail vein. The mice were killed $16 \mathrm{~h}$ after fungal inoculation and the lungs were removed under aseptic conditions, weighed and manually homogenized in PBS $(100 \mu \mathrm{L}$ to $20 \mathrm{mg}$ of tissue). Lung samples were cultured on $\mathrm{BHI}$ agar plates supplemented with $4 \%$ horse serum, $5 \%$ growth factor ${ }^{11}$ and $1 \%$ penicillin and streptomycin solution and the number of $\mathrm{CFU} / \mathrm{g}$ of tissue was calculated. For histological analysis, the lungs were routinely processed for the preparation of paraffin-embedded tissue sections and stained with hematoxylin-eosin (HE).

The following primersITS1 (5'-TCCGTAGGTGAACCTGCGG-3') and ITS4 (5'-TCCTCCGCTTATTGATATGC-3'), described elsewhere ${ }^{12}$, were used in the snPCR. The primer MJ03 (5'-GTCTCAGACGTCAAAGCTCC-3') was designed by 
comparing sequences from $P$. brasiliensis and genetically close species, B. dermatitidis, C. immitis, H. capsulatum and S. schenckii. The MJ03 primer was used with ITS1 primer in the second round PCR to generate a fragment of $212 \mathrm{bp}$. The first round PCR consisted of $5 \mu \mathrm{l}$ of DNA sample in a total volume of $25 \mu \mathrm{l}$, with $20 \mathrm{mM}$ Tris- $\mathrm{HCl},(\mathrm{pH}$ $8.4 ; 50 \mathrm{mM} \mathrm{KCl}), 1.5 \mathrm{mM}$ of $\mathrm{MgCl}_{2}, 0.2 \mu \mathrm{M}$ of primers ITS 1 and ITS4, $1 \mathrm{U}$ of Taq polymerase (Invitrogen, Brazil), and $0.25 \mathrm{mM}$ of dNTP (Amresco). The reaction mixture of the second round PCR was identical, except that $1 \mu \mathrm{l}$ of the first reaction product and the inner primer pair ITS1 and MJ03 were used. The PCR was performed in a thermal cycler (MWG Biotech) programmed as follows: $95^{\circ} \mathrm{C}$ for $2 \mathrm{~min} ; 30 \mathrm{cycles}$ of $95^{\circ} \mathrm{C}$ for $30 \mathrm{sec}, 55^{\circ} \mathrm{C}$ for $30 \mathrm{sec}, 72^{\circ} \mathrm{C}$ for $1 \mathrm{~min}$; and $72^{\circ} \mathrm{C}$ for $5 \mathrm{~min}$. The quality of DNA extracted from mice tissues was evaluated by PCR using GAPDH primers ${ }^{2}$. PCR products were analyzed by electrophoresis on an $8 \%$ polyacrylamide gel, stained with silver nitrate. In order to evaluate the specificity of the primers, genomic DNA templates (25ng) from all fungi cited above were tested. The lower detection limit was determined using genomic DNA of $P$. brasiliensis LDR1, and using mice lungs spiked with serial dilutions of $P$. brasiliensis.

To evaluate snPCR with clinical biopsy, samples of lesions from 5 patients with an initial clinical diagnose of PCM from University Dentistry Center at the State University of Londrina, Brazil were used. The samples were stored at $-20^{\circ} \mathrm{C}$ until DNA extraction. This study was approved by the Ethics Committee of the Londrina State University, Brazil.

As expected, in the first reaction, amplicons of different sizes were generated with DNA of all the fungi tested (Figure 1A). The second round PCR only amplified a fragment of $212 \mathrm{bp}$ with DNA of P. brasiliensis, thus showing the specificity of this reaction (Figure 1B). In relation to sensitivity, the test was able to detect $0.25 \mathrm{pg}$ of $P$. brasiliensis DNA (Figure 1C) and in mice lungs samples spiked with yeast cells from P. brasiliensis, it detected as few as 10 yeast cells (Figure 1D).

The histopathological analysis and snPCR were able to detect $P$. brasiliensis in all the samples tested, while culture was positive in three out of five mice samples (Table 1).

In clinical samples from patients with an initial clinical diagnose of PCM, the snPCR for P. brasiliensis was positive in four out of five patients. The negative sample was from a patient later diagnosed with leishmaniasis (Figure 1E and Table 2).

Molecular biological methods for detection and characterization of microorganisms have revolutionized diagnostic microbiology and the PCR technique is of great importance in this respect. The snPCR described here uses the universal to fungi ITS1 and ITS4 primers and the MJ03 primer that is specific for $P$. brasiliensis. This specific primer was design comparing sequences from GenBank database and anneals to the internal transcribed spacer 1 (ITS1) variable region.

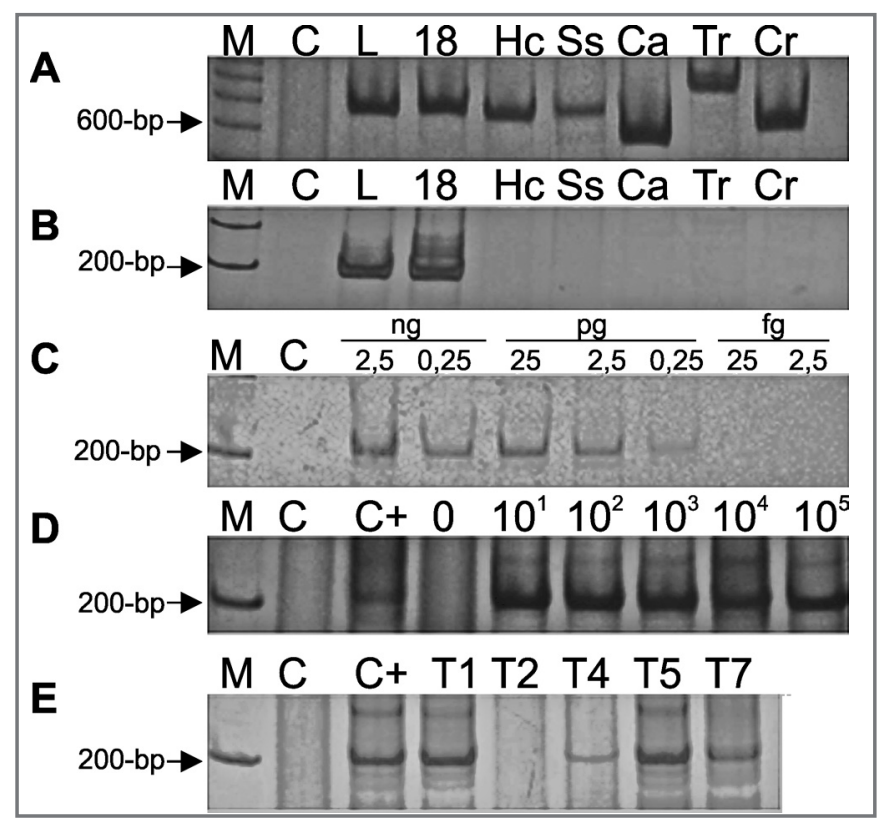

FIGURE 1 - Specificity and sensitivity of the semi-nested PCR assay. A) First round of semi-nested with primers ITS1 and ITS4. B) Second round of seminested with primers ITS1 and MJ03. C) The detection limit of semi-nested PCR (ITS1 and MJ03) with DNA from P. brasiliensis Ldr1 isolate. D) Detection limit of lung tissue spiked with 0 to $10^{5}$ yeast cells of $P$. brasiliensis. E) Detection in clinical samples. M: 100bp DNA Ladder (Invitrogen, Brazil), C: Negative control, C+: Positive control, L: P. brasiliensis Ldr1 isolate, 18: P. brasiliensis Pb18 isolate; Hc: H. capsulatum, Ss: S. schenckii, Ca: C. albicans (CR15), Tr: T. rubrum, Cr: Cryptococcus sp, T1- T7: tissue samples from patients, $8 \%$ polyacrylamide gel stained with silver nitrate.

TABLE 1 - Detection of $P$. brasiliensis in lung tissue of mice 16 hours after inoculation of the fungus.

\begin{tabular}{lcccc}
\hline \multicolumn{5}{c}{ Results for } \\
\cline { 2 - 5 } Mouse no. & CFU/g of lung & (HE stain) & semi-nested PCR & GAPDH PCR \\
\hline C1 & 0 & - & - & mice \\
C2 & 0 & - & - & + \\
3 & $1 \times 10^{4}$ & + & + & + \\
4 & 0 & + & + & + \\
5 & 0 & + & + & + \\
6 & $4 \times 10^{3}$ & + & + & + \\
7 & $2.3 \times 10^{3}$ & + & + & + \\
\hline C: control, +: positive, $-:$ negative, GAPDH: glyceraldehyde 3-phosphate dehydrogenase gene.
\end{tabular}

In a preview study using the ITS1-5.8S-ITS2 region as target, an unexpected cross-reaction with $H$. capsulatum was observed ${ }^{6}$. In this study, the snPCR was specific for P. brasiliensis and no amplification product was observed with DNA from the other tested fungi; moreover, it showed greater sensitivity than some previous

TABLE 2 - Patient clinical data.

\begin{tabular}{lccccccc}
\hline & \multicolumn{5}{c}{ Patients } \\
\cline { 2 - 7 } & sex & occupation & tobacco & alcohol & biopsy & histopathology & molecular \\
smokers & consumption & & PCM diagnosis \\
\hline T1 & M (35) & machine operator & no & chronic & alveolar ridge & oral PCM & positive \\
T2 & M (33) & driver & no & not chronic & palate & leishmaniosis & negative \\
T4 & M (38) & farmer & yes & chronic & lip & oral PCM & positive \\
T5 & M (44) & bricklayer & yes & not chronic & vestibular fornix & oral PCM & positive \\
T7 & M (61) & farmer & yes & nonalcoholic & alveolar ridge & oral PCM & positive \\
\hline
\end{tabular}


reports ${ }^{10}$ and similar to a nested PCR assay for S. schenckii ${ }^{13}$. The high sensitivity in the present test is probably the result of choosing the high copy number ITS1-5.8S-ITS2 region ${ }^{14}$ in association with snPCR, recognized as having a 1,000-fold greater sensitivity than conventional PCR. Furthermore, detection of amplicons by polyacrylamide gels/silver nitrate methodology is recognized as more sensitive than agarose and ethidium bromide detection.

To show the potential application of this snPCR for the molecular detection of $P$. brasiliensis in clinical samples, mouse lung samples spiked with yeast cells from $P$. brasiliensis and positive results were obtained with as few as 10 yeast cells. Similar results were observed with a PCR assay for the detection of $P$. brasiliensis in spiked sputum samples ${ }^{3}$.

Furthermore, the comparative testamong culture, histopathological analysis and snPCR performed using experimentally infected mice, showed that histopathological analysis and snPCR were slightly more sensitive than culture.

In clinical samples from patients with an initial clinical diagnose of PCM, the snPCR for P. brasiliensis was positive for four patients, and negative for a sample, later diagnosed as leishmaniasis, a disease with lesions that can resemble oral PCM lesions. The diagnoses were later confirmed by histopathological analysis.

The semi-nested PCR described in this study is a rapid (approximately 12 hours), specific and sensitive method and was useful for detecting the presence of $P$. brasiliensis DNA in culture and tissue.

\section{ACKNOWLEDGMENTS}

The authors would like to thank MA Ono, HO Saridakis, I Felipe and RMB Quesada for providing the fungi strains and isolates used in this study.

\section{CONFLICT OF INTEREST}

The authors declare that there is no conflict of interest.

\section{FINANCIAL SUPPORT}

This study was partial supported by the Coordenação de Aperfeiçoamento de Pessoal de Nível Superior and the Conselho Nacional de Desenvolvimento Científico e Tecnológico, Brazil.

\section{REFERENCES}

1. Lacaz CS. Mycological diagnosis. In: Franco F, Lacaz CS, Restrepo A, Negro GD, editors. Paracoccidioidomycosis. Boca Raton: CRC Press; 1994. p.339-344.

2. Bialek R, Ibricevic A, Aepinus C, Najvar LK, Fothergill AW, Knobloch J, et al. Detection of Paracoccidioides brasiliensis in tissue samples by a nested PCR assay. J Clin Microbiol 2000; 38:2940-2942.

3. Gomes GM, Cisalpino PS, Taborda CP, Camargo ZP. PCR for diagnosis of paracoccidioidomycosis. J Clin Microbiol 2000; 38:3478-3480.

4. Nakagawa EI, Uno J, Sano A, Yarita K, Kamei K, Miyaji MK, et al. Detection of the gp43 gene and (1-3)-beta-D-glucan of Paracoccidioides brasiliensis in the blood of experimentally infected mice. Nippon Ishinkin Gakkai Zasshi 2002; 43:29-35.

5. Imai T, Sano A, Mikami Y, Watanabe K, Aoki FH, Branchini ML, et al. A new PCR primer for the identification of Paracoccidioides brasiliensis based on rRNA sequences coding the internal transcribed spacers (ITS) and $5 \times 8$ regions. Med Mycol 2000; 38:323-326.

6. Motoyama AB, Venâncio EJ, Brandao GO, Petrofeza-Silva S, Pereira IS, Soares CM, et al. Molecular identification of Paracoccidioides brasiliensis by PCR amplification of ribosomal DNA. J Clin Microbiol 2000; 38:3106-3109.

7. Sano A, Yokoyama K, Tamura M, Mikami Y, Takahashi I, Fukushima K, et al. Detection of gp43 and ITS1-5.8S-ITS2 ribosomal RNA genes of Paracoccidioides brasiliensis in paraffin-embedded tissue. Nippon Ishinkin Gakkai Zasshi 2001; 42:23-27.

8. Theodoro RC, Candeias JM, Araujo JP, Bosco SM, Macoris SA, Padula LO, et al. Molecular detection of Paracoccidioides brasiliensis in soil. Med Mycol 2005; 43:725-729.

9. Ricci G, Silva ID, Sano A, Borra RC, Franco M. Detection of Paracoccidioides brasiliensis by PCR in biopsies from patients with paracoccidioidomycosis: correlation with the histopathological pattern. Pathologica 2007; 99:41-45.

10. San-Blas G, Nino-Veja G, Barreto L, Hebeler-Barbosa F, Bagagli E, Briceno RO, et al. Primers for clinical detection of Paracoccidioides brasiliensis.J Clin Microbiol $2005 ; 43: 4255-4257$.

11. Castañeda E, Brummer E, Perlman AM, McEwen JG, Stevens DA. A culturemedium for Paracoccidioides brasiliensis with high plating efficiency, and the effect of siderophores. J Med Vet Mycol 1988; 26:351-358.

12 White TJ, Bruns T, Lee S, Taylor J. Amplification and direct sequencing of fungal ribosomal RNA genes for phylogenetics. In. Innis MA, Gelfand DH, Sninsky JJ, White TJ, editors. PCR Protocols: A Guide to Methods and Applications. San Diego: Academic Press; 1990. p. 315-322.

13. Hu S, Chung WH, Hung SI, Ho HC, Wang ZW, Chen CH, et al. Detection of Sporothrix schenckii in clinical samples by a nested PCR assay. J Clin Microbiol 2003; 41:1414-1418.

14. Atkins SD, Clark IM. Fungal molecular diagnostics: a mini review. J Appl Genet 2004; 45:3-15. 